\title{
SPIRITUAL ENTREPRENEURSHIP DI PESANTREN ENTREPRENEUR AL-MAWADDAH KUDUS
}

\author{
M. Sofyan Alnashr \\ Institut Pesantren Mathali'ul Falah Pati \\ Email: sofyan@ipmafa.ac.id \\ Muhammad Labib \\ Peneliti Muda Pusat FISI IPMAFA \\ Email: mubammad.labib6666@gmail.com
}

\begin{abstract}
This study aims to map spiritual values that encourage Pesantren Entrepreneur Al-Mawaddah to conduct entrepreneurship movements and their application in real action. This research is a field research with qualitative-descriptive method which took place at the Pesantren Entrepreneur AlMawaddah, Honggosoco Village, Jekulo, Kudus. As a method of searching data, interview, observation and documentation techniques have been carried out. Then, in the analysis phase has been used Miles and Huberman analysis techniques with 4 stages of analysis; collecting data, data reduction, data display, verification and drawing conclusions. The results of this study have mapped Core Values Abli Sorga (which contains 9 values) as a spiritual value that encourages Pesantren Al-Mawaddah to develop entrepreneurship. This value is the result of reflection and internalization of the gusjigang ideology inherited from Sunan Kudus. These spiritual values have been implemented by pesantren in the form of: (1) pesantren which are honest and trustworthy in carrying out various business fields and safeguarding the products of the community, (2) charity activities in the form of mass circumcision and orphanage, sewing skills training and make snacks, agricultural technology training, (3) balance in carrying out ibadatullah (compulsory worship, recitation of kitab kuning) and imarathul ardh in the form of entrepreneurship development, (4) formulation of vision and action conducted by founders and caregivers from a young age, encouraging santri to have similar visions and missions. (5) making Core Values Abli Sorga as an autosuggestion in santri to have the spirit of entrepreneurship.
\end{abstract}

Keywords: Spiritual Entrepreneruship, Pesantren, Entrepreneur.

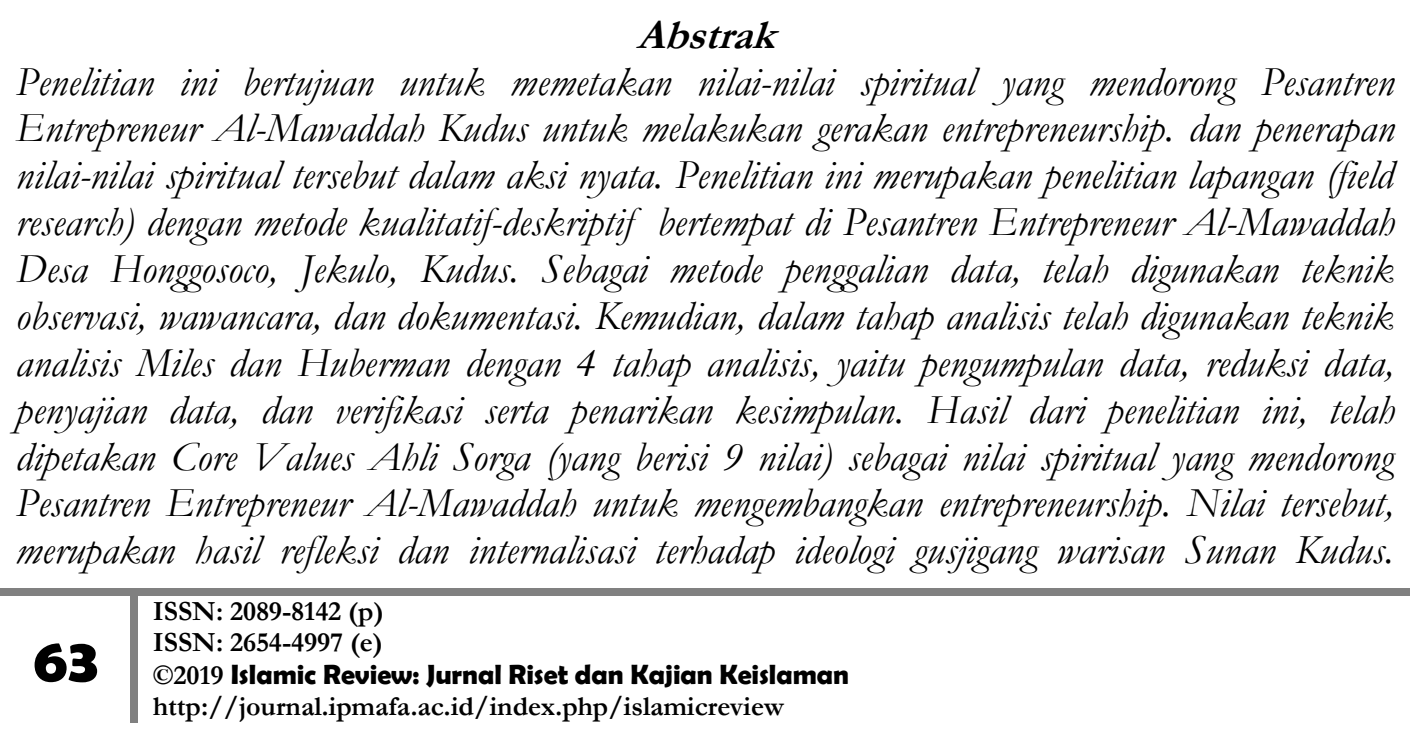


Nilai-nilai spiritual ini, telah diterapkan secara nyata oleh pesantren berupa (1) jujur dan amanah dalam menjalankan berbagai bidang usaha dan menjaga produk titipan masyarakat, santri yang jujur dan amanah menjalankan tugas entrepreneurship, (2) kegiatan charity berupa khitan masal dan santunan anak yatim, pelatiban keterampilan menjahit dan membuat makanan ringan bagi Jam'iyyah pengajian Al-Mawaddah, serta pelatihan teknologi pertanian bagi masyarakat Kudus dan sekitarnya. (3) kesesimbangan dalam menjalankan ibadatullah (ibadah wajib, pengajian kitab, dan lainnya), serta kepentingan imarathul ardh berupa pengembangan entrepreneurship, (4) perumusan visi dan aksi yang dilakukan oleh pendiri dan pengasub sejak usia muda, mendorong santri memiliki visi dan misi serupa. (5) menjadikan core values Abli Sorga sebagai autosugesti dalam diri santri untuk memiliki semangat entrepreneurship.

Kata Kunci: Spiritual Entrepreneruship, Pesantren, Entrepreneur.

\section{A. Pendahuluan}

Pesantren yang sejak dahulu menjadi pusat pendidikan keagamaan Islam di Indonesia, sangat erat sekali hubungannya dengan pendidikan dan praktek penghayatan spiritualitas. Terdapat nilai-nilai seperti teosentris, pengabdian, kearifan, kesederhanaan, kebersamaan, kemandirian, dan restu kiai yang sangat erat sekali bagi kalangan pesantren. ${ }^{1}$ Khusus nilai kemandirian, pesantren sangat gencar dalam menyampaikannya. Pesantren benar-benar mendorong supaya menghindarkan diri dari keadaan fakir dan meminta-minta. Hal itu, menjadi salah satu kajian sehari-hari di dalam literatur kitab kuning yang dipelajari.

Sementara itu, spiritualitas yang dipelajari di pesantren ini dirasa belum diejawantahkan secara konkret. Spiritualitas baru diejawantahkan dalam materi pengajian kitab kuning, atau sedikit mendekati konkret, hanya diwujudkan dalam bentuk riyadhoh, puasa sunah, wirid, memperbanyak salat sunah dan amalanamalan ritual agama Islam lainnya yang hanya mengarah kepada hubungan vertikal antara manusia dengan Tuhan.

Dalam hal ini, terdapat keadaan paradoks bahwa pesantren yang kental dengan ajaran spiritualitas dalam materi pegajian kitab kuningnya, tetapi justru dalam realitanya, pengejawentahan dari materi pengajian itu belum dipraktekkan secara konkret. Hal ini dikarenakan adanya pemahaman yang parsial mengenai materi pengajian di dalam kitab kuning disiplin ilmu tasawuf yang acap kali mencela kehidupan dunia.

\footnotetext{
${ }^{1}$ Hariadi, Evolusi Pesantren, (Yogyakarta: LkiS, 2015), hlm. 66-70.
} 
Pengejawantahan spiritualitas yang hanya diwujudkan dalam bentuk ritual keagamaan, belum dapat memperlihatkan peran dan kontribusi pesantren secara konkret bagi pembangunan dan penyelesaikan problematika yang ada di Indonesia. Pesantren yang telah medapatkan pengakuan resmi secara nasional dengan diresmikannya tanggal 22 Oktober sebagai Hari Santri Nasional harus mulai menyadari peran dan tanggungjawabnya bagi Indonesia. Jika tidak demikian, dikhawatirkan pesantren akan menjadi seperti kerajaan-kerajaan kecil di tengah masyarakat muslim, dengan kekuatan yang besar dan kiai yang duduk di singgah sana di atas menara gading, tanpa turut berkontribusi aktif menyelesaikan problematika Indonesia.

Termasuk sebagai problem Indonesia yang tidak pernah terselesaikan secara tuntas adalah problem pengangguran. Berbagai program mulai dari periode pemerintahan Soekarno hingga sekarang pemerintahan Joko Widodo, masih menyisakan jutaan penduduk yang menganggur. Problem ini memang sangat kompleks dengan berbagai latar belakangnya. Upaya meminimalisir jumlahnya adalah ikhtiar yang bisa dilakukan oleh pemerintah dan semua pihak yang terkait.

Dikutip dari situs resmi Badan Pusat Statistik (BPS), Jumlah angkatan kerja pada Agustus 2017 sebanyak 128,06 juta orang. Dari jumlah tersebut, sebanyak 121,02 juta orang penduduk bekerja dan sebanyak 7,04 juta orang menganggur. Dibanding tahun sebelumnya, jumlah penduduk bekerja dan pengangguran masing-masing bertambah 2,61 juta orang dan 10 ribu orang. Sementara itu, jumlah penduduk usia kerja 15 tahun ke atas yang memilih untuk berwirausaha baru mencapai angka 23.147.482 orang. ${ }^{2}$

Menyambung analisis data di atas, menurut Erlina Zahar, dengan mengutip pernyataan Anak Agung Gede Ngurah Puspayoga selaku Menteri Koperasi dan UKM (dalam Kompas, 2017) mengatakan bahwa rasio wirausaha Indonesia mengalami kenaikan, yang sebelumnya hanya 1,67\% menjadi 3,1\% dari sekitar 225 juta penduduk. Dengan demikian, tingkat entrepreneurship di

\footnotetext{
2 Badan Pusat Statistik (BPS), Statistik Tenaga Kerja Indonesia 2017, https://www.bps.go.id/subject/6/tenaga-kerja.html, diakses pada tanggal 6 September 2018, pukul 11.36 WIB
} 
Indonesia telah melampaui $2 \%$ dari jumlah penduduk, sebagai syarat minimal suatu negara dikatakan makmur. Tetapi, rasio tersebut masih rendah apabila dibandingkan dengan negara-negara ASEAN lainnya seperti Singapura yang memiliki 7\% pengusaha, Malasyia yang memiliki 5\% pengusaha, dan Thailand yang memiliki $4 \%$ pengusaha. ${ }^{3}$

Dengan adanya masalah di atas, partisipasi dari berbagai pihak bangsa Indonesia sangat dibutuhkan, termasuk dalam hal ini adalah pesantren. Berdasarkan data pengurus Bagian Data, Sistem Informasi dan Hubungan Masyarakat, Sekretariat Direktorat Jenderal Pendis Kemenag, pada tahun 2016 jumlah pesantren di Indonesia sebanyak 28.194 pesantren yang tersebar baik di wilayah kota maupun pedesaan dengan jumlah total santri mencapai 4.290.626 anak. ${ }^{4}$ Data tersebut, mengandung kesimpulan bahwa secara kuantitatif pesantren memiliki kekuatan besar di Indonesia, dan sangat memungkinkan untuk membentuk sebuah pergerakan konkret.

Kemudian, menjadi relevan apabila pergerakan konkret yang ditawarkan sebagai ikhtiar untuk menyelesaikan problem pengangguran dan meningkatkan produktivitas wirausaha di Indonesia, berupa pergerakan entrepreneurship. Pergerakan ini bukanlah pergerakan yang keluar atau menentang spiritualitas yang erat kaitannya dengan pesantren. Justru, pergerakan ini merupakan bagian dari pengejawentahan spiritualitas secara lebih konkret, sebagaimana pendapat Sahal Mahfudh yang menjelaskan bahwa pesantren sebagai lembaga pendidikan dan sosial keagamaan memiliki tanggung jawab untuk turut mengatasi problematika sosial dengan gerakan konkret. Konsep yang ditawarkan adalah tentang gerakan pengembangan masyarakat yang termasuk di dalamnya berupa gerakan entrepreneurship. ${ }^{5}$ Gerakan tersebut, merupakan bagian dari manifestasi empat pola hubungan manusia, yaitu hubungan manusia dengan Allah,

\footnotetext{
3 Erlina Zahar, Pendidikan Entrepreneurship Guna Mempersiapkan Mahasiswa dalam Menghadapi Persaingan Masyarakat Ekonomi Asean (MEA), Jurnal Ilmiah DIKDAYA, Vol. 7, No.2, 2017, hlm. 56.

4 Agus Yulianto, "Pertumbuhan Pesantren di Indonesia Dinilai Menakjubkan", https://www.republika.co.id/berita/dunia-islam/islam-nusantara/17/11/30/p088lk396-

pertumbuhan-pesantren-di-indonesia-dinilai-menakjubkan. Telah diakses pada tanggal 5 September 2018, pukul 13.17 WIB.

5 Uyu Wahyudin, Pelatihan Entrepreneurship Berlatar Ekokultural untuk Pemberdayaan Masyarakat Miskin Pedesaan, Jurnal MIMBAR, vol. XXVIII, No. 1, 2012, hlm. 60-61.
} 
hubungan manusia dengan manusia, hubungan manusia dengan alam, serta hubungan manusia dengan hidup dan kehidupan. ${ }^{6}$

Untuk merealisasikan tujuan ini, dibutuhkan sosok pesantren yang mampu menjadi percontohan. Tidak hanya pesantren yang melakukan pengejawentahan spiritualitas berupa ritual keagamaan Islam dan rutinitas tafaqquh fiddin semata, tetapi juga melakukan gerakan entrepreneurship. Dari ribuan pesantren yang ada, Pesantren Entrepreneur Al-Mawaddah yang terletak di Desa Honggosoco, Jekulo, Kudus, merupakan salah satu pesantren yang telah melakukan prinsip di atas.

Dengan berlandasakan pada ideologi warisan Sunan Kudus gusjigang (bagus, ngaji, dagang), tiga semboyannya berupa leadership, entrepreneurship, dan spiritual, serta core values Ahli Sorga, selain melakukan rutinitas salat dan wirid berjamaah, tahfiz. Al-Qur'an, serta pengajian kitab kuning seperti Ibya' Ulumiddin karya Al-Ghazali ${ }^{7}$, pesantren ini juga akitf mengembangkan entrepreneruship dengan turut melibatkan santri untuk mengelola berbagai bidang usaha, mulai dari eduwisata, mini market, pertamini, dan perkebunan buah naga. ${ }^{8}$

Berdasarkan latar belakang di atas, penulis terdorong untuk melakukan penelitian di Pesantren Al- Mawaddah tersebut. Sebagai batasan masalah dalam penelitian ini, telah disusun dua rumusan inti pembahasan, yaitu: (1) Nilai-nilai spiritual yang mendorong gerakan entrepreneurship di Pesantren Entrepreneur AlMawaddah Kudus, serta (2) implementasi konkret dari nilai-nilai tersebut dalam aksi nyata.

Selaras dengan rumusan masalah di atas, maka penelitian ini bertujuan untuk memetakan nilai-nilai spiritual yang mendorong Pesantren Entrepreneur Al-Mawaddah untuk melakukan gerakan entrepreneurship dan penerapannya dalam aksi nyata. Penelitian ini juga diharapkan dapat memperluas kajian keislaman dan kepesantrenan di dalam dunia akademik yang menggabungkan antara nilai-nilai spiritual dan konsep gerakan entrepreneurship, memberikan gambaran dan

\footnotetext{
${ }^{6}$ MA. Sahal Mahfudh, Pesantren Mencari Makna, (Jakarta: Fatma Press, 1999), hlm.1-14.

7 Anis Khoirun Nisa Wahidiyyah, Wawancara Pribadi, pada Tanggal 17 April 2018, pukul 13.00 WIB

8 Sofiyan Hadi, Wawancara Pribadi, Pendiri dan Pengasuh Pesantren Entrepreneur Al-Mawaddah Kudus, Tanggal 10 April 2018, pukul 09.00 WIB.
} 
dorongan praktek semangat spiritual entrepreneurship kepada dunia akademik, pesantren lain, dan masyakat umum, serta menjadi dorongan khusus kepada Pesantren Entrepreneur Al-Mawaddah Kudus untuk lebih berkembang lagi.

Kemudian, sebagai usaha untuk menghindari tindakan plagiasi, telah ditelusuri beberapa hasil penelitian terdahulu yang serupa dengan judul penelitian yang diangkat oleh penulis. Sejauh penelusuran yang dapat dilakukan, ditemukan tiga hasil penelitian yang dimaksud, yaitu :

Penelitian Abdul Jalil dengan judul "Spiritual Entrepreneurship: Transformasi Spiritualitas Entrepreneurship" merupakan hasil penelitian terhadap beberapa pelaku usaha di Kudus mulai kelas bawah hingga atas. Dari penelitian ini, dipetakan 10 nilai spiritual entrepreneurship yang dipraktekkan oleh para pengusaha di Kudus, yaitu: amanah, sustainable, kontrol diri, komparatif, empathy, taktis, kreatif, mandiri, sinergis dan belajar dari gagal yang menjadi transformasi dari spiritualitas mereka dalam proses usaha dari awal hingga berjalan sukses.

Skripsi Maziyatul Aqliyah dengan judul 'Strategi Meningkatkan Kemampuan Santri di Bidang Kewirusahaan dalam Menghadapi Masyarakat Ekonomi ASEAN (MEA) (Studi Kasus di Ponpes Al-Mawaddah Honggosoco Kudus)', bertujuan untuk mengetahui pengembangan entrepreneurship bagi santri Pesantren Al-Mawaddah Kudus dan bagaimana strategi meningkatkan kemampuan santri dibidang entrepreneurship untuk menghadapi Masyarakat Eknomi ASEAN (MEA). Hasil penelitian ini menunjukkan bahwa; (1) Dengan berpegang pada basis semboyan leadership, entrepreneurship, dan spiritual, Al-Mawaddah telah melakukan serangkaian pengajaran, pelatihan dan bimbingan, serta fasilitas atau wahana praktek dengan melibatkan secara aktif santri dan masyarakat sekitar untuk mengembangkan entrepreneurship, (2) strategi yang diterapkan untuk menyiapkan santri dalam menghadapi MEA adalah (a) Meningkatkan kompetensi dan produktivitas para santri, (b) Memberikan kursus bahasa Arab dan Inggis bagi para santri, (c) Mengembangkan kreativitas para santri dalam berwirausaha, (d) Pengembangan SDM Ponpes. Al-Mawaddah.

Penelitian Muharromiyati dan Suyahmo yang berjudul "Pewarisan Nilai Falsafah Budaya Lokal Gusjigang sebagai Modal Sosial di- Pesantren Entrepreneur Al- 
Mawaddah Kudus".' Penelitian ini bertujuan untuk mendeskripsikan bagaimana Pesantren Entreprenur Al-Mawaddah melestarikan nilai lokal gusjigang menjadi spirit untuk melakukan aksi nyata di bidang entrepreneurship. Penelitian tersebut, menghasilkan kesimpulan: (1) Gusjigang falsafah dari spirit Sunan Kudus yang mengandung nilai karakter. Nilai karakter yang terkandung di dalamnya, meliputi Gus (bagus) meliputi jujur, toleransi, disiplin, peduli sosial, dan tanggung jawab. $J i$ (ngaji) meliputi religius, rasa ingin tahu, gemar membaca. Gang (dagang) meliputi kerja keras, kreatif, dan mandiri. (2) Pola pewarisan yang dilakukan oleh pondok yaitu dengan pola partisipatif. (3) Bentuk pewarisan nilai karakter Gusjigang melalui internalisasi dan sosialisasi. Adapun modal sosial yang dibutuhkan yaitu kepercayaan, jaringan, norma, kreativitas dan kemandirian (4) Alasan pondok mengembangkan nilai karakter yang berpijak pada falsafah Gusjigang yaitu pewarisan nilai melalui kecerdasan budaya, pelestarian budaya lokal, membangun kemandirian ekonomi dan menumbuhkan semangat peduli lingkungan.

\section{B. Landasan Teori}

Abdul Jalil memaparkan bahwa terdapat beberapa hasil penelitian yang telah menunjukkan integrasi antara spiritualitas dan bisnis (entrepreneurship). Seperti hasil penelitian Patricia Aburdene dalam Megatren 2010, Danah Zohar dan Ian Marshall dalam Spiritual Quotient, dan Stephen Covey dalam The $8^{\text {th }}$ Habit. Selain dengan adanya hasil penelitian tersebut, dengan mengutip pendapat James Sinamo, Jalil berpendapat bahwa kesadaran para pengusaha akan pentingnya spiritualitas, disebabkan oleh efek samping dari problem industri dalam bisnis berupa rusaknya alam, mekanisasi penumpukan beban kerja, kecurangan, ketimpangan, dan stress berat, yang menggiring mereka kepada proses dehumanisasi yang membuat produktivitasnya menurun. ${ }^{10}$

Menurut Yudhiana Prastiwi dengan mengutip pendapat Yopi, mendefiniskan spiritual entrepreneur sebagai orang-orang yang menjalankan bisnisnya dengan tetap mempertimbangkan nilai-nilai etika dan agama. Jika

\footnotetext{
${ }^{9}$ Muharromiyati \& Suyahmo, Pewarisan Nilai Falsafah Budaya Lokal Gusjigang sebagai Modal Sosial di Pesantren Entrepreneur Al-Mawaddah Kudus, Journal of Educational Social Studies, Vol. 5, No. 2, 2016.

${ }^{10}$ Abdul Jalil, Spiritual Enterpreneurship: Transformasi Spiritualitas Entrepreneurship, hlm.7- 17.
} 
dihubungkan dengan Islam, maka islamic spiritual entrepreneuship adalah berbisnis dalam urusan duniawi yang sangat berhubungan erat dengan akhirat, serta tetap mengutamakan rambu-rambu agama. ${ }^{11}$

Sementara itu, Abdul Jalil mendefinisikan spriritual bisnis sebagai proses transendensi untuk membentuk lembaga bisnis melampaui pengertian bisnis sendiri, seperti yang selama ini dipahami. Spiritualitas bisnis tidak hanya berbicara tentang profit, transaksi, manajemen, accounting, dan strategi, namun juga mempersoalkan pelayanan, pengembangan, tanggung jawab sosial, lingkungan hidup, dan keadilan. ${ }^{12}$

Maka, berangkat dari dua definisi di atas dapat disimpulkan bahwa spiritual entrepreneurship adalah proses pengejawentahan spiritualitas yang dulunya hanya berada dalam dimensi batin yang sakral dan diwujudkan dalam bentuk ritual kegamaan, menjadi sebuah pergerakan konkret yang membawa kebermanfaatan dan kerahmatan bagi seluruh alam.

Entrepreneurship yang merupakan kegiatan bisnis praktis, jika di-nisbatkan kepada pesantren, bukan merupakan sesuatu yang keluar atau bertentangan dengan spiritualitas. Hal ini disampaikan oleh Sahal Mahfudh yang menjelaskan bahwa pesantren sebagai lembaga pendidikan dan sosial keagamaan memiliki tanggung jawab untuk turut mengatasi problematika sosial dengan gerakan konkret. Konsep yang ditawarkan adalah tentang gerakan pengembangan masyarakat yang termasuk di dalamnya berupa gerakan entrepreneurship. ${ }^{13}$ Gerakan tersebut, merupakan bagian dari manifestasi empat pola hubungan manusia, yaitu hubungan manusia dengan Allah, hubungan manusia dengan manusia, hubungan manusia dengan alam, serta hubungan manusia dengan hidup dan kehidupan. $^{14}$

Untuk membantu penulis dalam melihat secara utuh tentang penerapan spiritual entrepreneurship di Pesantren Al-Mawaddah, maka penulis menggunakan

11 Yudhiana Prastiwi, Skripsi: Islamic Spiritual Entrepreneurship Pedagang Pasar Cemani Sukoharjo, (Surakarta: IAIN Surakarta, 2017), hlm. 10.

12 Abdul Jalil, Spiritual Enterpreneurship: Transformasi Spiritualitas Entrepreneurship..., hlm.18.

13 Uyu Wahyudin, Pelatihan Entrepreneurship Berlatar Ekokultural untuk Pemberdayaan Masyarakat Miskin Pedesaan..., hlm. 60-61.

${ }^{14}$ MA. Sahal Mahfudh, Pesantren Mencari Makna, (Jakarta: Fatma Press, 1999), hlm.1-14. 
teori organisasi dan manajemen dengan pendekatan sistem sebagai kaca mata untuk melakukan analisis.

Teori ini, memiliki asumsi dasar bahwa organisasi itu selalu berinteraksi dengan lingkungannya dan mencapai suatu keadaan mantap (steady state) atau keseimbangan dinamis dengan tetap mempertahankan kapasitasnya untuk trasnsformasi energi. Sistem ini harus menerima input sumberdaya yang cukup untuk dapat mempertahankan operasinya, dan mengelurakan output berupa sumberdaya yang sudah diubah untuk lingkungannya sebagai tanggung jawab sosial dalam jumlah yang cukup untuk meneruskan daur sistem tersebut. ${ }^{15}$

Lebih jelas lagi, Kast dan Rosenzweig menerangkan bahwa organisasi bisa dianggap sebagai subsistem dari lingkungan sosiokultural yang sedang beroperasi. Organisasi merupakan bagian dari sistem sosial yang dijalankan untuk mencapai sasaran tertentu, yaitu 'masyarakat' dengan pandangan dan pemaknaan sistem yang inklusif. Oleh karena itu, nilai organisasi tersebut sangat dipengaruhi oleh norma dan ideologi masyarakat. Nilai di sini merupakan dasar utama yang dijadikan pedoman untuk mengambil keputusan dan tindakan, yang selanjutnya menentukan kerangka kerja dasar, serta pengembangan organisasi berikut manajemennya. ${ }^{16}$

Organisasi adalah adanya dua orang atau lebih yang saling mengikat diri untuk melakukan kerja sama melalui struktur tertentu dalam mencapai tujuan (goals) atau sekumpulan tujuan (a set of goals) yang telah disepakati bersama. Untuk mengelola sebuah organisasi, diperlukan cara pengelolaan tertentu yang disebut dengan manajemen, yaitu proses yang dilakukan organisasi untuk merencanakan, mengorganisasikan, mengarahkan, dan mengendalikan seluruh kegiatan anggota organisasi dengan menanfaatkan berbagai sumber daya yang tersedia untuk mencapai tujuan bersama. ${ }^{17}$

Proses alur pengaruh yang terjadi antara kedua variable di atas, tidak berlangsung dengan pola satu arah, melainkan keduanya saling mempengaruhi

\footnotetext{
${ }^{15}$ Fremont E. Kast \& James E. Rosenzweig, Hasyim Ali (Penerjemah), Organisasi \& Manajemen, (Jakarta: Bumi Aksara, 1990), hlm. 154.

${ }^{16}$ Fremont E. Kast \& James E. Rosenzweig, Hasyim Ali (Penerjemah), Organisasi \& Manajemen, hlm. 32-33.

${ }^{17}$ Agus Sabardi, dkk, Meraih Tujuan dengan Manajemen, (Yogyakarta: STIE YKPN, 2004), hlm. 4.
} 
satu sama lain. Satu sisi, sistem sosiokultural mempengaruhi nilai di dalam organisasi dan manajemen. Sementara itu, di sisi lain sistem sosiokultural menjadi obyek yang dipengaruhi. Kast dan Rosenzweig mencontohkan fenomena program kesejahteraan sosial yang disponsori oleh pemerintah, program kompensasi pengangguran, dan program perawatan kesehatan, dimana mereka bisa tercetuskan karena ada masalah di dalam sistem sosial, dan ketika sudah dijalankan mereka cenderung mempengaruhi pandangan tradisional masyarakat tentang individualisme dan swa-sembada (self-sufficiency). Demikian juga yang terjadi antara lembaga pendidikan dan masyarakat, atau lembaga bisnis dan masyarakat, terdapat pola hubungan saling mempengaruhi yang dinamis. ${ }^{18}$

\section{Metode Penelitian}

Penelitian ini termasuk dalam jenis penelitian lapangan (field research), yang bersifat deskriptif dengan pendekatan kualitatif. Jenis penelitian yang berusaha menggambarkan masalah-masalah yang diteliti sesuai dengan keadaan apa adanya tanpa ditambah dan dikurangi. ${ }^{19}$ Lalu, data yang telah diperoleh ditafsirkan apa adanya oleh peneliti dan dianalisa secara induktif. ${ }^{20}$ Lokasi penelitian, bertempat di Pesantren Entrepreneur Al-Mawaddah, Honggosoco, Jekulo, Kudus, Jawa Tengah.

Sebagai sumber data primer, sesuai arahan pengasuh Al-Mawaddah telah dipilih beberapa nama untuk diwawancarai, yaitu KH. Sofiyan Hadi, Lc. MA. Pengasuh Pesantren Entrepreneur Al-Mawaddah, Hj. Khadijah Al Hafidzah Istri Pengasuh, Ustadz Nur Sa'id. Salah satu ustadz yang mengampu pengajian kitab, Rois selaku koordinator pemantauan petani binaan, Empat orang santri putra dan dua orang santri putri.

Sedangkan untuk data sekundernya, telah ditelusuri situs blog Pesantren Entrepreneur Al-Mawaddah, akun youtube Al-Mawaddah, dan berbagai situs berita online yang memuat berita tentang Pesantren Al-Mawaddah.

Dalam penentuan sumber data, telah digunakan teknik purposive sampling, yaitu proses pengambilan informan sebagai sumber data dengan pertimbangan

${ }^{18}$ Fremont E. Kast \& James E. Rosenzweig, Hasyim Ali (Penerjemah), Organisasi \& Manajemen, hlm. 32-40.

${ }^{19}$ Dadang Kuswana, Metode Penelitian Sosial, (Bandung: Pustaka Setia, 2011), hlm.37-38.

${ }^{20}$ Sugiyono, Metode Penelitian Kuantitatif, Kualitatif, dan R\&D, (Bandung, Alfabeta, 2008), hlm. 8-9. 
tertentu. Misalnya, sampel yang dipilih dianggap sebagai orang yang paling memahami pemetaan data di lapangan, dan juga teknik snowball sampling, yaitu teknik pengambilan sampel sumber data yang pada awalnya sedikit, lama-lama menjadi besar. ${ }^{21}$

Sebagai metode pengumpulan data, telah digunakan teknik-teknik sebagai berikut; (a) Wawancara Bertahap atau Bebas Terpimpin, yaitu jenis wawancara ini, dilakukan secara bebas dan juga mendalam (in-depth), tetapi kebebasan tersebut harus sesuai koridor pokok masalah dan sebelum wawancara dimulai, peneliti telah menyiapkan pertanyaan, (b) Observasi Tidak Berstruktur, yaitu observasi yang dilakukan tanpa menggunakan guide. Maka, peneliti harus mampu mengembangkan daya pengamatannya dalam proses pengamatan., (c) Metode dokumentasi, yaitu metode yang digunakan untuk menelusuri data historis. Metode ini digunakan sebagai metode pengumpulan data yang tersedia dalam bentuk surat-surat, catatan harian, cindera mata, laporan, dan lain sebagainya. ${ }^{22}$

Kemudian, dalam teknik analisis data telah dipakai teknik analisis model Miles dan Huberman dengan 4 tahapan, yaitu: (a) Collecting Data (Mengumpulkan Data), (b) Data Reduction (Reduksi Data), (c) Data Display (Penyajian Data), dan (d) Conclusion Drawing/Verification. ${ }^{23}$

\section{Hasil Penelitian}

\section{1) Peta Nilai-Nilai Spiritual di Pesantren Entrepreneur Al-Mawaddah}

Pesantren Al-Mawaddah memiliki keunikan yang jarang dimiliki oleh pesantren pada umumnya. Selain melakukan kegiatan pendidikan kegamaan Islam, pesantren ini menjadikan entrepreneurship sebagai pendidikan dan praktek yang terintergrasi di dalam pesantren, atau bisa dikatakan menjadi rub pengembangan secara kokrit. Bahkan, secara eksplisit istilah entrepreneur disandarkan menjadi nama tengah pesantren ini.

${ }^{21}$ Sugiyono, Metode Penelitian Kuantitatif, Kualitatif, dan R\&D, hlm. 218-219.

22 Burhan Bungin, Analisis Data Penelitian Kualitatif, (Jakarta: Rajawali Pers, 2007), hlm. 113-127.

${ }^{23}$ Emzir, Metodologi Penelitian Kualitatif: Analisis Data, (Jakarta: Rajawali Pers, 2010), hlm. 129-136. 
"Gusjigang itu kan singkatan dari Bagus, Ngaji dan Dagang. Filosofi itu memang menjadi motor penggerak babkan menjadi prinsip berdirinya pesantren Al-Mawaddah ini. ${ }^{, 24}$

Berdasarkan apa yang disampaikan oleh ketua pondok II di atas, dapat disimpulkan bahwa Al-Mawaddah berdiri dan berkembang atas dasar filosofi gusjigang, yaitu sebuah akronim yang terdiri dari bagus, ngaji, dan dagang. Tidak hanya santri saja yang memiliki keyakinan seperti itu. Hal yang sama diakui oleh salah satu ustaz yang mengampu pengajian kitab di pesantren tersebut.

"Al-Muhafadzatu ala al qadim as-sholih, wal akhdzu bil jaded, al-ashlah. Yang baik kita lestarikan, yang lebih baik kita ambil. Ini prinsip pesantren. Maka nilai-nilai seperti bagus, ngaji, dagang, ini kita lestarikan. Tidak hanya dilestarikan, tapi kita kembangkan. Kita kembangkan menjadi sebuah landasan dalam berperilaku, bagaimana membangun umat islam yang kuat labir maupun batin."25

Filosofi gusjigang tidak hanya menjadi landasan atau latar belakang pendirian pesantren ini, berikut pengembangannya, tetapi juga menjadi spirit untuk mencapai tujuan yang diharapkan oleh Al-Mawaddah berupa umat Islam yang kuat lahir dan batin. Hal ini mengandung kesimpulan bahwa gusjigang memang telah menjadi filosofi yang sangat berpengaruh bagi perkembangan AlMawaddah. Hal ini pula yang secara tegas dan jelas diakui oleh pendiri dan pengasuh Al-Mawaddah, bahwa :

"Iadi, spiritual Al-Mawaddah itu apa? yaitu penggabungan antara spiritual dan material. Tidak ada pembedanya. Maka dari itu, semangatnya adalah semangat 'gusjigang' sebauah warisan dari Sunan Kudus. ${ }^{, 26}$

Pernyataan dari pendiri dan pengasuh Al-Mawaddah ini, secara jelas menyebutkan bahwa memang gusjigang merupakan spirit yang menginspirasi beliau untuk mendirikan pesantren tersebut. Istilah gusjigang sendiri, diakui oleh beliau merupakan semangat masyarakat Kudus, khususnya Kudus bagian kulon

\footnotetext{
${ }^{24}$ Anis Khoirun Nisa Wahidiyyah, Wawancara Pribadi, Ketua Pondok II (Pondok Putri) Pesantren Entrepreneur Al-Mawaddah Kudus, pada 17 April 2018, pukul 13.00 WIB.

25 Nur Said, Wawancara Pribadi, salah satu ustadz pengampu pengajian kitab di Pesantren Entrepreneur Al-Mawaddah Kudus, pada 17 April 2018, pukul 13.00 WIB.

26 Sofiyan Hadi, Wawancara Pribadi, Pendiri dan Pengasuh Pesantren Entrepreneur Al-Mawaddah Kudus, pada 20 April 2018, pukul 09.30 WIB.
} 
atau Barat yang diwariskan oleh Raden Ja'far Sadiq, atau yang dikenal dengan Sunan Kudus.

Pendiri dan Pengasuh Al-Mawaddah menjelaskan bahwa gusjigang merupakan tahapan pengembangan yang ditanamkan kepada santri dan masyarakat luas, yang terdiri dari: (1) bagus (spiritual), yaitu Al-Mawaddah memiliki semangat untuk memberi teladan dan mengajarkan kepada santrinya untuk memiliki akhlak yang bagus dan sopan, serta sederhana tidak bermegahmegahan, (2) ngaji (intelektual melahirkan leadership), artinya setelah bagus akhlaknya, seseorang harus memperkaya dan mengembangkan intelektualitasnya. Hal ini berhubungan dengan batasan kriteria santri yang mondok di AlMawaddah, yaitu harus mahasiswa yang dipandang lebih dewasa dan bisa berkomitmen dalam rangkaian kegiatan di Al-Mawaddah, maka, dengan prinsip ini setiap santri yang mondok di Al-Mawaddah diharapkan memiliki jiwa leadership yang kuat, (3) dagang (entrepreneruship), artinya setelah mencapai kedua hal di atas, dagang dianggap buah saja dalam hubungannya dengan praktek entrepreneruship. ${ }^{27}$

Al-Mawaddah merupakan sebuah lembaga organisasi yang menjadi salah satu subsistem dalam sebuah supra-sistem sosial yang ada di Kudus. Dalam proses pendirian hingga perkembangannya, telah ditemukan fakta di lapangan dari beberapa informan di atas, bahwa perkembangan Al-Mawaddah tidak bisa terlepas dari pengaruh filosofi gusjigang yang telah dikenal, bahkan menjadi pedoman hidup bagi masyarakat Kudus secara luas. Gusjigang telah menginspirasi Al-Mawaddah untuk komitmen fokus pada aktivitas entrepreneurship yang diajarkan kepada para santri dan masyarakat luas.

Selanjutnya, sebagai bentuk hasil refleksi dan internalisasi Al-Mawaddah terhadap ideologi gusjigang sebagai bagian dari supra-sistem sosial di Kudus, pendiri Al-Mawaddah menyusun nilai-nilai khas yang digunakan untuk menjadi pendorong setiap aktivitas tafaqquh fiddin dan aktivitas entrepreneurship. Nilai-nilai khas itu, disebut dengan core values Ahli Sorga. Berikut uraiannya:

27 Sofiyan Hadi, Wawancara Pribadi, Pendiri dan Pengasuh Pesantren Entrepreneur AlMawaddah Kudus, pada 20 April 2018, pukul 09.30 WIB. 


\section{A-dd Values/Menambah nilai.}

Kami adalah pribadi dan kelompok yang selalu meberikan nilai tambah bagi mitra bisnis, bagi lingkungan sekitar dan masyarakat dunia. Kami meyakini bahwa keberadaan kami adalah untuk memberikan manfaat terbaik kepada seluruh alam semesta. Segala sesuatu yang kami lakukan dan kami impikan adalah untuk memberikan kontribusi positif bagi keberlangsungan dan keseimbangan kehidupan di muka bumi ini.

\section{H-igh Performance/Berkinerja Tinggi.}

Bekerja dan melayani dengan baik saja, tidak cukup bagi kami. Kami bekerja dengan predikat yang luar biasa, melebihi prestasi tertinggi rata-rata orang lain. Kami selalu proaktif, berusaha keras, kreatif, dan inovatif mencari cara-cara terbaik, untuk memberikan hasil terbaik dan untuk meraih impianimpian kami. Kami bekerja dengan cepat dan tuntas untuk membentu rekan kerja, team, dan mitra bisnis, meraih hasil yang telah direncanakan dengan efetivitas dan efesiensi yang tinggi.

3. L - earn, Grow, and Fun/Senantiasa Belajar, Mengembangkan Diri, dan Menuntaskan Tugas dengan Bersemangat.

Segala kejadian yang kami alami, kami lihat, kami dengar dan kami rasakan adalah pelajaran bagi kami. Agar kami menjadi pribadi dan kelompok yang senantiasa melakukan perbaikan. Kami senantiasa meluangkan waktu untuk menambah pengetahuan dan meningkatkan keterampilan, agar kami terus berkembang menjadi lebih baik, sehingga mampu memberikan solusi yang tepat bagi setiap tantangan yang dihadapi oleh organisasi, mitra bisnis, dan lingkungan sekitar. Kami adalah AHLI SORGA yang selalu bersemangat dalam melaksanakan kewajiban dan selalu bersemangat dalam menuntaskan tugas yang menjadi tanggung jawab kami. Kami menciptakan situasi yang selalu riang dan gembira untuk mendukung pencapain kinerja terbaik yang kami impikan.

\section{I-ntegrity and Commitment (Amanah dan Berkomitmen).}

Kami adalah pribadi, organisasi dan kelompok AHLI SORGA yang dapat dipercaya. Kami adalah orang-orang yang amanah, bertanggung jawab, dan berdisiplin tinggi. Kami menjunjung tinggi dan menjaga kepercayaan yang 
diberikan kepada kami. Kami selalu siap memberikan komitmen dan partisipasi $100 \%$ prinsip-prinsip AHLI SORGA. Kami berusaha keras melaksanakan semua hal yang telah kami rencanakan, kami katakan, dan kami janjikan.

5. S-yar'ie ( Mengamalkan dan Menegakkan Syari'ah Islam).

Kami menjalani kehidupan di dunia ini semata-mata untuk beribadah kepada Allah SWT. Senantiasa berusaha keras untuk melaksanakan perintahperintah-Nya dan meninggalkan larangan-larangan-Nya. Kami melakukan sesuatu dengan niat ikhlas karena Allah dan dengan cara yang sesuai dengan syari'ah Islam. Kami berfikir, bersikap, dan berperilaku Islami pada setiap aspek kehidupan sehari-hari. Di manapun kami berada, kami selalu mengusahakan persatuan dan kesatuan kaum muslimin. Kami selalu aktif berpartisipasi 100\% dalam setiap aktivitas dakwah untuk menegakkan syari'ah Islam demi kejayaan Islam dan kemuliaan kaum muslimin.

6. $O$-ptimist Visionary (Optimis Menata Masa Depan).

Impian-impian besarlah yang menggerakkan kami. Kami menyadari bahwa semua yang kami dapatkan saat ini adalah hasil dari semua yang telah kami lakukan dan kami berikan sebelumnya. Oleh karena itu, kami selalu berfikir besar, bermimpi besar, dan bertindak besar. Kami sangat yakin bahwa Allah selalu menolong kami untuk mewujudkan impian-impian besar kami. Kami sangat meyakini bahwa Allah selalu bersama kami untuk mewujudkan impian-impian besar kami.

\section{7. $R$-espect Others (Menghormati dan Menghargai Orang lain).}

Masing-masing dari kami selalu saling menghargai hasil usaha dan kontribusi pihak lain. Keterbukaan dan kejelasan informasi dan komunikasi sangat penting bagi kami. Pada setiap tingkatan hirarki dan kepentingan, kami selalu saling membuka diri untuk perbaikan kualitas kinerja kami. Kami menyadari bahwa untuk mencapai keberhasilan, penting bagi kami untuk bekerja sama dan saling percaya satu sama lain. Kami saling terbuka, saling menghargai, dan saling membantu untuk bersama-sama memberikan hasil terbaik yang telah direncanakan.

\section{G-o Extra Miles (Melakukan Sesuatu Melebihi Standar).}


Kami menyadari sepenuhnya bahwa untuk menjadi AHLI SORGA, menjadi yang terbaik dan memberikan yang terbaik, kami sudah memutuskan untuk melakukan sesuatu melebihi standar dan rata-rata orang lain. Kami berusaha keras untuk konsisten menjaga sikap, mental seorang pejuang, sampai kami meraih keberhasilan atau kami mati ketika mengusahakannya. Kami membiasakan diri untuk memberi lebih dari pada yang kami terima. Kami selalu berusaha untuk berbuat yang terbaik dan gemar melakukan kebaikan yang kami mampu untuk perbaikan kehidupan manusia di muka bumi ini.

\section{A-bbundance and Grateful (Berkelimpahan dan Bersyukur).}

Berkelimpahan adalah sikap kami. Keberlimpahan arus kas dan keuntungan merupakan sesuatu yang selalu kami usahakan. Kami meyakini bahwa kelangsungan usaha yang kami tekuni, jika dan hanya jika usaha tersebut memberikan hasil yang berlimpah. Selalu berbagi dan bersyukur adalah sikap kami. Segala usaha kami lakukan untuk menciptakan dan berbagi keberlimpahan dan kemakmuran yang seimbang antara materi, kemanusiaan, etika dan spiritual. Kami menyadari bahwa apa yang terjadi, yang kami alami, kami dengar, dan kami rasakan saat ini adalah yang terbaik yang Allah berikan kepada kami. Kami bersyukur atas semua itu. Kami meyakini dengan senantiasa bersyukur kami mampu mengerahkan potensi untuk memberikan kontribusi terbaik kami. ${ }^{28}$

\section{2) Penerapan Nilai-Nilai Spiritual dalam Mengembangkan Entrepreneurship di Al-Mawaddah}

a) Pesantren yang jujur dan amanah

Penerapan yang dilakukan oleh pengasuh yang diwujudkan dalam hal memfasilitasi titipan produk masyarakat sekitar untuk dijual di mini market pesantren. Tidak hanya menjual produk dari pesantren sendiri, di mini market "Harmonik" milik Al-Mawaddah juga menerima titipan produk masyarakat berupa makanan ringan (ceriping ketela, ceriping dari senthik (sejenis ubi-ubian),

${ }_{28}$ Data diperoleh dari dokumen arsip Pesantren Entrepreneur Al-Mawaddah yang diambil pada tanggal 17 April 2018, pukul 12.00 WIB. 
dan beras hasil tani masyarakat. Tanpa mengambil keuntungan sebagian dari hasil penjualan atau potongan imbal jasa penitipan, pesantren secara utuh memberikan keuntungan hasil penjualan barang tersebut kepada masyarakat sekitar yang menitipkan produk. ${ }^{29}$

Penerapan yang dilakukan oleh santri, yang diwujudkan dalam kejujuran dan amanah dalam mengemban tugas entrepreneurship yang diberikan. Selain memberi fasilitas tafaqquh fiqqin, Al-Mawaddah juga mendorong kreatifitas dan keterampilan santri dengan memberikan ruang kepada santri untuk latihan berentrepreneurship dengan ikut menjaga beberapa bidang usaha Al-Mawaddah. Berbagai bidang usaha itu, memiliki omzet yang tidak sedikit. Berdasarkan pengakuan pengasuh, sejak Al-Mawaddah berdiri hingga sekarang tidak pernah terjadi kasus penyelewangan laporan keuangan, penggelapan, maupun pencurian yang dilakukan oleh santri. ${ }^{30}$

\section{b) Kegiatan charity dan program pelatihan entrepreneurship.}

Dalam kegiatan charity, Al-Mawaddah memiliki dua program rutin yang dilakukan setiap tahun, yaitu santunan anak yatim yang diselenggarakan setiap satu tahun dua kali pada bulan Muharram dan bulan Rajab, serta khitan massal yang diselenggarakan setiap bulan Muharram. ${ }^{31}$

Kemudian, untuk pelatihan entrepreneurship, Al-Mawaddah telah menerapkannya dalam 2 jenis program, yaitu: (1) Pelatihan Keterampilan bagi Jam'iyyah Pengajian Al-Mawaddah yang beranggotakan 125 ibu-ibu santri yang mengaji Al Qur'an dan Tafsirnya bersama Ibu Hj. Khadijah dan KH. Sofiyan Hadi setiap hari Minggu pagi. Mereka berasal dari Jekulo, Mejobo, Bae, dan Nggebok. Mereka telah diberi pelatihan keterampilan dalam membuat makanan ringan hasil kerjasama dengan 'Tepung Boga Sari'. dan pelatihan bordir, hasil kerjasama dengan 'Industri Bordir Hida' salah satu industri teskstil ternama di Kudus. Tidak berhenti pada pelatihan saja, tetapi terdapat beberapa santri yang

\footnotetext{
${ }^{29}$ Nur Chalimatus Sa'diyah, Wawancara Pribadi, Pengurus Departemen Kewirausahaan, 17 April 2018, pukul 12.00 WIB.

${ }^{30}$ Sofiyan Hadi, Wawancara Pribadi, Pendiri dan Pengasuh Pesantren Entrepreneur Al-Mawaddah Kudus, pada 20 April 2018, pukul 09.30 WIB. Dibenarkan pula oleh Ahmad Mashudin sebagai santri senior yang menyatakan tidak pernah terjadi kasus-kasus pencurian.

${ }^{31}$ Hasil Observasi di Pesantren Al-Mawaddah pada tanggal 11 April 2018, pukul 20.00 WIB.
} 
membuka usaha makanan ringan sebagai home industry dan ada pula yang direkrut untuk menjadi karyawan di 'Industri Bordir Hida'. ${ }^{32}$

(2) Pelatihan teknologi pertanian telah diselenggarakan oleh Al-Mawaddah sejak tahun 2011 yang dipercaya sebagai lembaga Pusat Pelatihan Pertanian Pedesaan Swadaya (P4S) tingkat Madya dengan SK resmi dari Kementerian Pertanian RI. Setiap tahun rutin diselenggarakan dua kali pelatihan bekerjasama dengan Dispertanak Kudus dengan jumlah peseta 40 orang setiap satu kali pelatihan. Peserta adalah masyarakat petani yang berasal dari daerah Kudus, Pati, dan Jepara. Tema pelatihan yang telah dikembangkan adalah pertanian tebu, ketela, dan kedelai. Tidak berhenti hanya di pelatihan, tetapi bagi masyarakat petani atau yang disebut sebagai petani binaan Al-Mawaddah menyatakan siap untuk dibina, akan dipantau dalam proses pertaniannya, dan dalam penjualan hasilnya akan dihubungan dengan pabrik industri professional seperti Indofood untuk petani ketela, dan Pabrik Gula Trangkil untuk petani tebu. ${ }^{33}$

\section{c) Kesimbangan antara ibadatullah dan imarathul ardh}

Al-Mawaddah sebagai lembaga yang kental dengan nuansa islam meyakini bahwa kehidupan harus dijalani secara seimbang. Hal itu berarti, manusia - yang dalam hal ini komunitas santri - seperti apa yang disampaikan oleh Sahal Mahfudh memiliki dua tugas hidup, yaitu beribadah kepada Allah dan juga melakukan imarathul ardh (mengelola dan memakmurkan isi bumi). ${ }^{34}$

Berkaitan dengan lingkup tugas 'ibadatullab (ibadah kepada Allah), seperti layaknya pesantren pada umumnya, setiap hari Al-Mawaddah rutin melakukan aktivitas salat lima waktu berjamaah, pengajian kitab kuning, pembacaan wirid, mujahadah, dan sholat malam. ${ }^{35}$

Kemudian, berkaitan dengan tugas 'imarathul ardh, Al-Mawaddah juga mewujudkannya dalam bentuk mengembangan berbagai bidang usaha yang inovatif. Tidak hanya menjalankan 7 badan usaha yang berwujud mulai dari

32 Ibu Nyai Hj. Khodijah, Wawancara Pribadi, Istri Pengasuh Al-Mawaddah pada 23 April 2018, pukul 11.00 WIB.

33 Sofiyan Hadi, Wawancara Pribadi, Pendiri dan Pengasuh Pesantren Entrepreneur AlMawaddah Kudus, pada 20 April 2018, pukul 09.30 WIB.

34 Umdah El Baroroh \& Tutik Nurul Janah, Fiqh Sosial: Masa Depan Fiqh Indonesia, (Pati, IPMAFA Press, 2016), hlm. 62.

${ }^{35}$ Lihat Profil Pesantren Entrepreneur Al-Mawaddah Kudus di BAB III. 
eduwisata, mini market, perkebunan buah naga, Al-Mawaddah juga mengembangkan budi daya ikan lele, metode tanam hidroponik dengan jenis tanaman daun mint, sawi, serta memiliki KRPL (Kawasan Rumah Pangan Lestari) atau sejenis kebun kecil yang berisi tanaman dapur mulai dari cabai, rempah-rempah, dan lain sebagainya. ${ }^{36}$

\section{d) Perumusan visi dan aksi}

Al-Mawaddah sejak berdirinya pada tahun 2008 hingga sekarang telah meraih berbagai respon positif, pengakuan, dan penghargaan. Mulai dari dipercaya sebagai Pusat Pelatihan Pertanian Pedesaan Swadaya (P4S) tingkat madya oleh Kementerian Pertanian sejak tahun 2012, Penghargaan Adhikarya Pangan Nusantara pada tahun 2015, penghargaan Kalpataru kategori Pembina lingkungan 2016 , dan lainnya. ${ }^{37}$

Pencapaian dan prestasi Al-Mawaddah tersebut tidak bisa terlepas dari sosok pendiri dan pengasuhnya, yaitu Kiai Sofiyan Hadi. Beliau mengakui bahwa salah satu bentuk usaha yang turut menentukan pencapaian Al-Mawaddah seperti sekarang adalah karena sejak masa sekolah beliau sering menuliskan impian-impian di buku kecil. Salah satu impian yang ditulis adalah bahwa beliau ingin memiliki lembaga independen yang kuat dalam hal ilmu pengetahuan dan kuat pula secara ekonomi.

Setelah itu, pengasuh Al-Mawaddah juga mendorong santrinya untuk memiliki impian-impian serupa (misi dreams) yang konkret bisa diwujudkan. Hal ini sebagaimana yang disampaikan oleh salah satu santri:

"abah dan umi juga selalu memotivasi bahwa sebagai seorang pemuda, santrisantri harus memiliki mimpin yang besar, kemudian direncanakan dengan baik, dan segara aksi. Kami dimotivasi supaya memiliki impian yang nyata, sehingga dapat dikejar. Orang yang tidak punya impian, maka hidupnya tidak. jelas, karena tidak ada yang dikejar..... ya.. kalau saya sib berharap nantinya bisa jadi pengusaha sukses yang berakblak mulia" 38

${ }^{36}$ Hasil Observasi di Pesantren Entrepreneur Al-Mawaddah Kudus pada 20 April 2018, pukul 09.30 WIB.

37 Dokumentasi Pesantren Entrepreneur Al-Mawaddah Kudus, diakses pada 20 April 2018, pukul 09.30 WIB.

38 Anis Khoirun Nisa Wahidiyyah, Wawancara Pribadi, Ketua Pondok II Pesantren Entrepreneur Al-Mawaddah Kudus, pada 17 April 2018, pukul 13.00 WIB. 
Dalam kajian praktik manajemen terdapat pula kajian tentang kepemimpinan (leadership) yang turut mempengaruhi maju-mundurnya sebuah organisasi tercakup di dalam tahap manajemen actuating. Menurut Abdurrahman Wahid, kepemimpinan kiai di pesantren itu sangat unik dalam arti mempertahankan ciri-ciri pramodern. Para santri menerima kepemimpinan kiainya karena mereka mempercayai konsep barakah, yang berdasarkan pada doktrin emanasi dari para sufi. Namun, menurutnya, hal ini bukan satu-satunya sumber. Ketaatan yang dilakukan oleh santri dengan penuh kesadaran, juga disebabkan oleh tradisi pra-Islam, yaitu tradisi Hindu, Budha mengenai hubungan gurusantri. Selain itu, salah satu doktri pula yang menlandasi hal tersebut, adalah adanya satu hadis yang menyebutkan bahwa 'ulama adalah pewaris para Nabi' ${ }^{39}$

Berdasarkan hasil wawancara dengan salah satu santri di atas, dengan gaya kepemimpinan pengasuh, santri-santri di Al-Mawaddah sudah merasa terarahkan untuk memiliki visi sebagai pengusaha sukses yang memiliki landasan akhlak mulia. Tidak hanya sekedar impian, tapi sudah ada 3 orang santri yang menekuni impiannya tersebut, yaitu dua orang santri putri yang merintis usaha jual beli pakaian dan kosmetik online, serta satu orang santri putra yang merintis usaha jasa video shooting. ${ }^{40}$

\section{e) Core Values Ahli Sorga sebagai Strategi Autosugesti}

Core Values Ahli Sorga yang bersisi 9 nilai inti, include ke dalam sebuah program yang unik di Al-Mawaddah. Setiap hari Minggu malam Senin, terdapat program pembacaan nilai tersebut secara berjama'ah oleh santri Al-Mawaddah setelah kegiatan khitobah. Teknis pembacaan berjalan dengan dimulai satu santri yang memimpin bacaan dan ditirukan oleh seluruh santri sambil membawa teks. $^{41}$

Dapat dipahami bahwa pembacaan core values Ahli Sorga yang menjadi kegiatan mingguan para santri, menunjukkan usaha Al-Mawaddah untuk menerapkan strategi pengarahan. Core values Ahli Sorga merupakan strategi

\footnotetext{
${ }^{39}$ Abdurrahman Wahid, Menggerakkan Tradisi, (Yogyakarta : LKiS, 2010), hlm. 234-136.

40 Anis Khoirun Nisa Wahidiyyah, Wawancara Pribadi, Ketua Pondok II (Pondok Putri) Pesantren Entrepreneur Al-Mawaddah Kudus, pada 17 April 2018, pukul 13.00 WIB.

41 Anis Khoirun Nisa, Wawancara Pribadi, Ketua II Pesantren Entrepreneur Al-Mawaddah Kudus, pada 17 April 2018, pukul 13.00 WIB.
} 
motivasi internal untuk mengatasi dan menghindarkan lack of motivation ${ }^{42}$ yang bisa terjadi pada santri Al-Mawaddah.

Dengan adanya pembacaan yang diulang-ulang, dan akronim yang mudah diingat, core values Ahli Sorga sangat mudah dihapal oleh santri, serta akan masuk ke dalam dimensi psikis santri. Core values Ahli Sorga ini lambat laun akan menjadi autosugesti yang mendorong santri untuk memiliki semangat entrepreneurship dengan berlandaskan pada kesadaran spiritual.

\section{E. Penutup}

Berdasarkan penelitian yang telah dilakukan tentang spiritual entrepreneurship di Pesantren Entrepreneur Al-Mawaddah Kudus, maka kesimpulan yang dapat dirumuskan adalah Pertama, nilai-nilai spiritual yang menjadi pendorong Pesantren Al-Mawaddah untuk melakukan aktivitas entrepreneurship adalah core values AHLI SORGA yang berisi 9 nilai inti (Add Values, High Perfromance, LearnGorw-and Fun, Integrity and Commitment, Syar'ie, Optimist Visionary, Respect Others, Go Extra Miles, Abbundance and Gratefull).

Kedua, Core values AHLI SORGA di Pesantren Al-Mawaddah telah diimplementasikan dalam aksi nyata berupa: (a) jujur dan amanah dalam menjalankan berbagai bidang usaha, terutama dalam menjaga amanah produk titipan masyarakat sekitar, serta santri yang jujur dan amanah dalam menjalankan tugas entrepreneurship. (b) Melakukan kegiatan charity berupa khitan masal dan santunan anak yatim, pelatihan keterampilan menjahit dan membuat makanan ringan, serta pelatihan teknologi pertanian, (c) menerapkan prinsip kesesimbangan dalam menjalankan dua kepentingan, yaitu kepentingan ibadatullah (ibadah wajib, sunnah, pengajian kitab), serta kepentingan imarathul ardh berupa pengembangan entrepreneurship dengan menjalanlan 7 jenis usaha. (d) Perumusan visi dan aksi yang dilakukan oleh pendiri dan pengasuh sejak usia muda untuk memiliki lembaga seperti Al-Mawaddah, serta mendorong santri untuk memiliki visi dan misi serupa. (e) Core Values AHLI SORGA dijadikan sebagai strategi untuk memunculkan autosugesti dalam diri santri untuk memiliki semangat entrepreneurship.

42 Agung Praptapa, The Art of Controlling People: Strategi Mengendalikan Perusahaan, Jakarta: Gramedia, 2009), hlm. 14-17. 


\section{Daftar Pustaka}

Antoni. 2014, Muslim Entrepreneurship: Membangun Muslimpreneurs Characteristics Dengan Pendekatan Knowladge Based Economy, Jurnal El-Hikam, Vol. VII, No. 23.

Badan Pusat Statistik (BPS), Statistik Tenaga Kerja Indonesia 2017, https://www.bps.go.id/subject/6/tenaga-kerja.html, diakses pada tanggal 6 September 2018, pukul 11.36 WIB.

Baroroh, Umdah El \& Tutik Nurul Janah. 2014, Figh Sosial: Masa Depan Fiqh Indonesia, Pati: IPMAFA Press.

Bula, Hannah Orwa. 2012, Evolution and Theories of Entrepreneurship: A Critical Review on the Kenyan Perspective, International Journal of Business and Commerce, Vol. 1, No.11.

Burhan, Bungin. 2007, Analisis Data Penelitian Kualitatif, Rajawali Pers, Jakarta.

Emzir. 2010, Metodologi Penelitian Kualitatif: Analisis Data, Jakarta : Rajawali Pers.

Hadi, Sofiyan, Wawancara Pribadi, Pendiri dan Pengasuh Pesantren Entrepreneur Al-Mawaddah Kudus, Tanggal 10 April 2018, pukul 09.00 WIB.

Hariadi. 2015, Evolusi Pesantren, Yogyakarta: LkiS.

Jalil, Abdul. 2014, Spiritual Entrepreneurship: Transformasi Spiritualitas Kewirausahaan, Yogyakarta: LKiS,.

Kast, Fremont E. \& Rosenzweig, James E., Hasyim Ali (Penerjemah). 1990, Organisasi \& Manajemen, Jakarta: Bumi Aksara.

Khadijah. 2014, Titik Temu Transpersonal Psychology dan Tasamuf, Teosofi: Jurnal Tasawuf dan Pemikiran Islam, Vol. 4, No. 2.

Kuswana, Dadang. 2011, Metode Penelitian Sosial, Bandung: Pustaka Setia.

Mahfudh, MA. Sahal . 1999, Pesantren Mencari Makna, Jakarta: Fatma Press.

Marlo, Abu. 2013, Entrepreneurship Hukum Langit, Jakarta: Gramedia Pustaka Utama.

Muharromiyati \& Suyahmo. 2016, Pewarisan Nilai Falsafah Budaya Lokal Gusjigang sebagai Modal Sosial di Pesantren Entrepreneur Al-Mawaddah Kudus, Journal of Educational Social Studies, Vol. 5, No. 2.

Praptapa, Agung. 2009, The Art of Controlling People: Strategi Mengendalikan Perusahaan, Jakarta: Gramedia. 
Prastiwi, Yudhiana. 2017, Skripsi: Islamic Spiritual Entrepreneurship Pedagang Pasar Cemani Sukobarjo, Surakarta: IAIN Surakarta.

Sa'diyah, Nur Chalimatus, Wawancara Pribadi, Pengurus Departemen Kewirausahaan, 17 April 2018, pukul 12.00 WIB.

Sabardi, Agus, dkk. 2004, Meraib Tujuan dengan Manajemen, Yogyakarta: STIE YKPN.

Said, Nur, Wawancara Pribadi, salah satu ustaz pengampu pengajian kitab di Pesantren Entrepreneur Al-Mawaddah Kudus, pada 17 April 2018, pukul 13.00 WIB.

Sugiyono. 2008, Metode Penelitian Kuantitatif, Kualitatif, dan R\&D, Bandung, Alfabeta. Suryana. 2013, Kewirausahaan: Kiat dan Proses Menuju Sukses, Jakarta: Salemba Empat. Wahid, Abdurrahman. 2010, Menggerakkan Tradisi, Yogyakarta: LKiS.

Wahidiyyah, Anis Khoirun Nisa, Wawancara Pribadi, pada Tanggal 17 April 2018, pukul 13.00 WIB

Wahyudin, Uyu. 2012, Pelatihan Entrepreneurship Berlatar Ekokultural untuk Pemberdayaan Masyarakat Miskin Pedesaan, Jurnal MIMBAR, vol. XXVIII, No. 1.

Yulianto, Agus, "Pertumbuhan Pesantren di Indonesia Dinilai Menakjubkan", https://www.republika.co.id/berita/dunia-islam/islamnusantara/17/11/30/p088lk396-pertumbuhan-pesantren-di-indonesia-dinilaimenakjubkan. Telah diakses pada tanggal 5 September 2018, pukul 13.17 WIB. Zahar, Erlina. 2017, Pendidikan Entrepreneurship Guna Mempersiapkan Mahasiswa dalam Menghadapi Persaingan Masyarakat Ekonomi Asean (MEA), Jurnal Ilmiah DIKDAYA, Vol. 7, No.2. 